Journal of Scientific Perspectives

Volume 4, Issue 3, Year 2020, pp. 217-222

E - ISSN: 2587-3008

URL: https://journals.gen.tr/jsp

DOİ: https://doi.org/10.26900/jsp.4.018

Research Article

\title{
CHIRP-ENGINEERING SEISMIC METHOD FOR EXPLORING SEABED AND UNDERWATER STRUCTURES: OFF-SHORE WESTERN ANATOLIA ${ }^{1}$
}

\author{
Savaş GÜRÇAY* \& Günay ÇİFÇİ** \\ * Assist. Prof. Dr., Canakkale Onsekiz Mart University, \\ Marine Technology Vocational School, TURKEY, \\ e-mail: savasgurcay@comu.edu.tr \\ ORCID: https://orcid.org/0000-0003-3402-787X \\ ** Prof. Dr., Dokuz Eylul University, \\ Instirute of Marine Sciences and Technology, TURKEY, \\ e-mail: gunay.cifci@deu.edu.tr \\ ORCID: https://orcid.org/0000-0002-4380-8056
}

\section{ABSTRACT}

CHIRP systems are widely used in seabed sediment classification, submarine faults, positioning of marine engineering structures, pipeline geotechnical studies, platform and well area assessments, archaeological and environmental impact assessments. The resolution of the system is in the order of decimeter. In this study, the characteristics of submarine active faults, buried faults, seabed and underlying layers in the region were analyzed and interpreted by CHIRP data collected off-shore Seferihisar, Teke Peninsula and Alaçatı.

Keywords: Submarine Active Faults, Buried Faults, CHIRP-Engineering Seismic. 


\section{INTRODUCTION}

Active faults and similar structures under the sea generally protect their structural features better since they are not exposed to negative external factors that occur over time as much as those on land. In addition, the seawater layer on it allows high resolution marine seismic methods (CHIRP, multi-beam bathymetry, side scan sonar etc.) to be applied.

This study covers off-shore Seferihisar, Teke Peninsula and Alaçatı, south of Izmir Bay. The study area and its surroundings are an important region in terms of active faults both on land and submarine. Karaburun Fault, Tuzla (Orhanl1) Fault, Urla Fault and İzmir Fault are the most important faults in the terrestrial area around the study area (Figure 1). All these faults can be traced on land to Kuşadası Bay and the surrounding coasts. There are a few previous studies involving the study area and its surroundings, using marine seismic methods. Aksu et al. (1987; 1990), mapped normal faults using the shallow marine seismic study carried out in İzmir Bay, Kuşadası Bay and its surroundings. In the marine seismic study carried out in the same area (Ocakoğlu et al., 2004; 2005), it was stated that the active tectonics of the study area is developing under the control of strike-slip faults.

Within the scope of this study, it has been tried to reveal how effective the method is in determining and analyzing active faults, buried faults and layers under the sea, as a result of processing and interpretation of CHIRP high resolution marine seismic reflection data collected off-shore Seferihisar, Teke Peninsula and Alaçatı.

Figure 1. Map of the area where the study area and the seismic profiles are located, active faults (Ocakoğlu et al., 2004; 2005) and focus mechanism of strong earthquakes (Benetatos et al., 2006, Tan and Taymaz 2001; Tan and Taymaz 2003). UF: Urla Fault, KF: Karaburun Fault, IF: İzmir Fault, TF: Tuzla Fault. The inner map shows the regional tectonics of the Anatolian microplate.

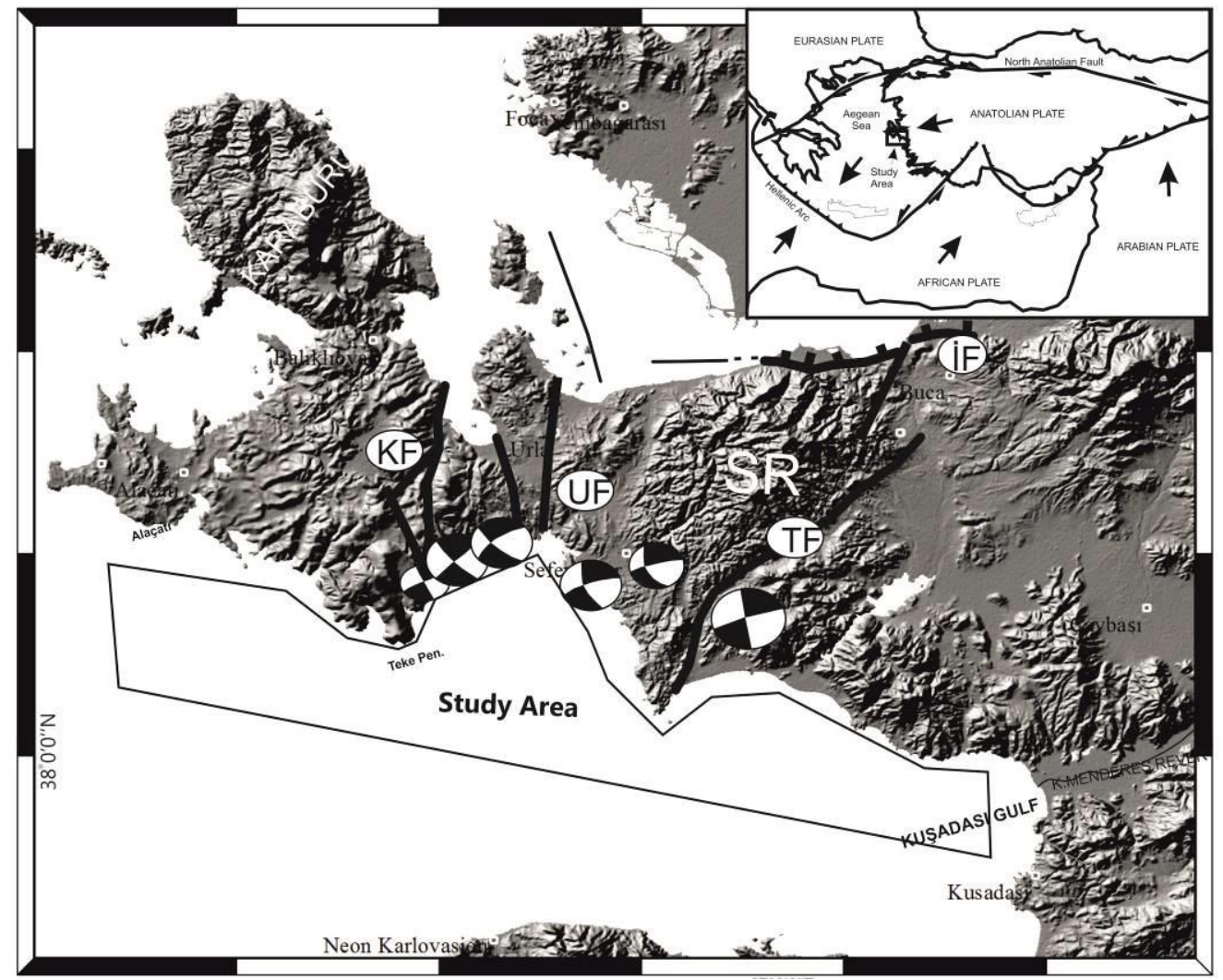




\section{METHOD}

During operation, high resolution engineering seismic (CHIRP) data was collected on the starboard side of the ship, with a $3.5 \mathrm{kHz}$ Bathy 2010 CHIRP system. Photos and schematic representation of the CHIRP system are given in Figure 2 and Figure 3. The signal emitted from the transducer is reflected from the seabed and the units underneath, and it is perceived by the transducer in the same way (Figure 2 and Figure 3).

The vertical resolution of CHIRP systems is dependent upon the bandwidth of the source. For example a $2-8 \mathrm{kHz}$ source equates to a theoretical vertical resolution of $0.125 \mathrm{~m}$, assuming compressional wave velocity of $1500 \mathrm{~m} \mathrm{~s}^{-1}$. The horizontal resolution of CHIRP systems is primarily dependent upon the source characteristics (beam angle, dominant frequency), compressional wave velocity of the sediments, towfish altitude and pulse rate of the system; with characteristic horizontal resolutions of 1 to $2 \mathrm{~m}$ (Quinn et al., 1998). For the processing of digitally recorded CHIRP data, Quinn et al. (1998) suggested a flow chart. Accordingly, processing of CHIRP data is carried out in 2 stages. In the 1st stage, correlation and deconvolution and in the 2 nd stage, filtering operations are performed.

Figure 2. CHIRP high resolution engineering seismic recorder and transducers

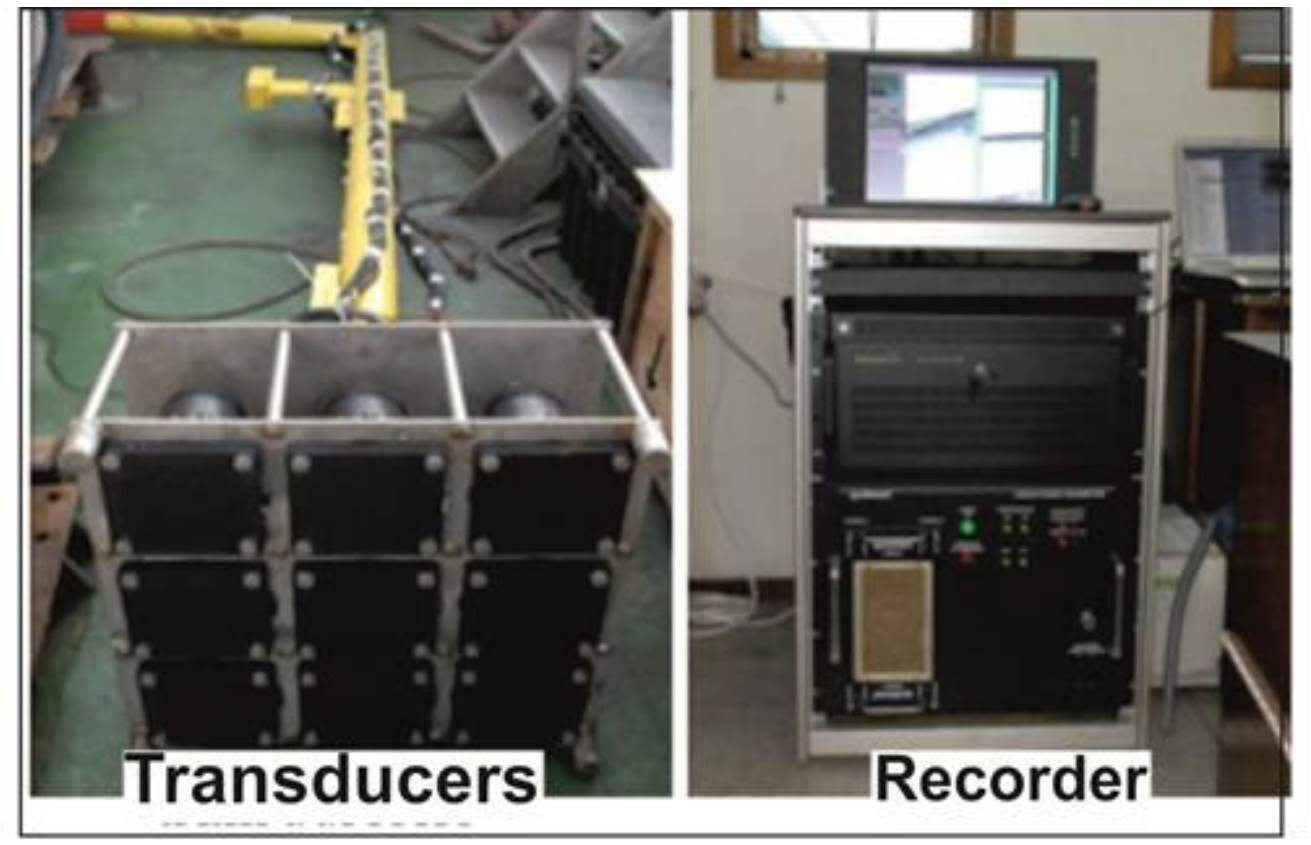


Figure 3. Block structure and working principle of high resolution engineering seismic systems (Çifçi et al., 2005)

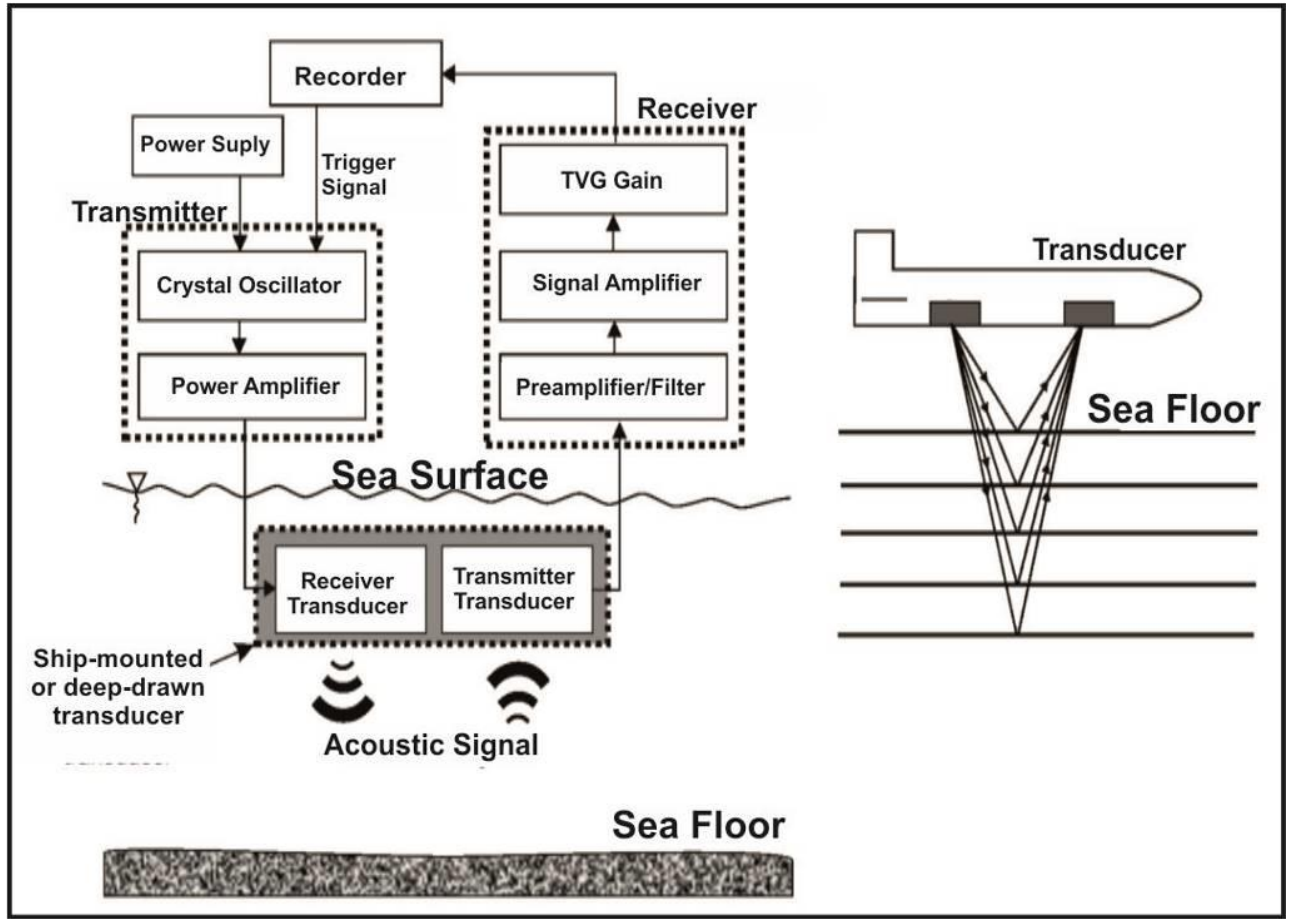

\section{INTERPRETATION OF CHIRP DATA}

From analyzed high resolution CHIRP marine seismic data the seabed, layers under the seabed, active faults cutting the layers, buried faults, slip distance on active faults can be clearly distinguished. In determining active and buried faults in sections, it is taken into account whether the layers under the sea are cut along these faults to the seabed. Just below the sea water column, the sea floor consisting of the young sediments and the faults reaching very close are interpreted as active fault in this study. Faults that could not reach the seabed were evaluated as buried faults (Figure 4).

Figure 4 shows a CHIRP section obtained from the study area. Here, it is seen that the sea deepens from the right to the left of the section. The young and Quaternary sediments that form the sea floor and the underlying layers show a parallel and uniform sedimentation. When the section is analyzed in terms of active faults, it is observed that these faults cut structural layers and sea-floor at the bottom of the sea and below. It is understood that the most important reason for these structural changes is due to the vertical slip on the active faults here (Figure 4). In Figure 4, it is seen that the location of the largest slip of the active faults is approximately at $1500 \mathrm{~m}$ offset to the left of the section and 550 milliseconds two-way traveltime depth. 
Figure 4. Active faults, buried faults and Quaternary Deposits observed on the CHIRPMarine Engineering Seismic section obtained from the study area.

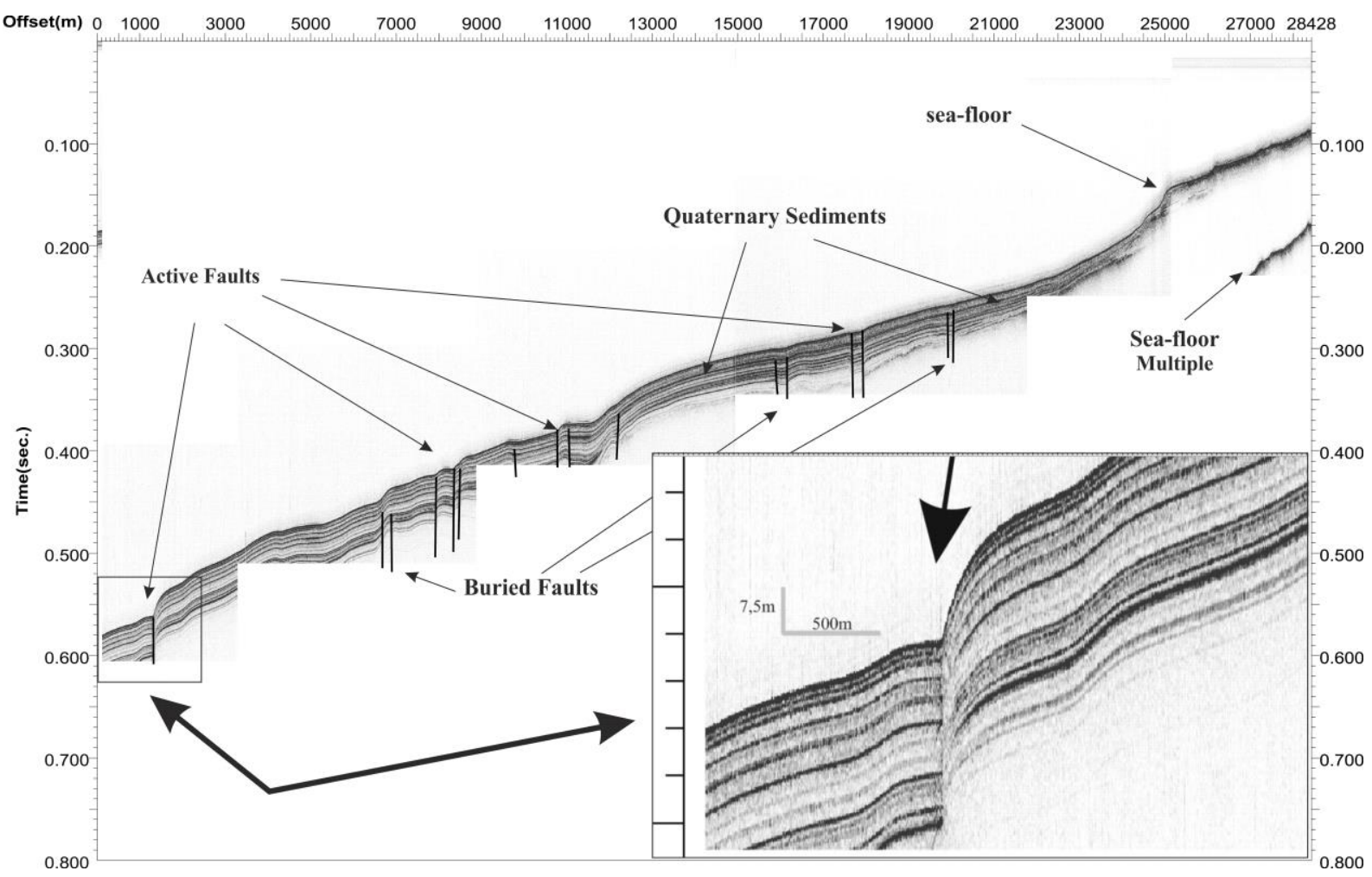

\section{CONCLUSIONS}

In this study, as a result of processing and interpretation of CHIRP data collected in Seferihisar, Tekeburnu and Alaçatı, the characteristics of submarine active faults, buried faults, seabed and underlying layers were investigated. Quaternary sediments generally show a parallel and regular sedimentation structure, while active and buried faults seem to cause lateral discontinuities and generally vertical slip in these sediments. In addition, as well as active faults, buried faults caused structural changes in the sea floor. This suggests that these buried faults may still keep their activity.

\section{ACKNOWLEDGEMENTS}

CHIRP high resolution marine seismic data were collected by K. Piri Reis research vessel, Dokuz Eylül University (D.E.Ü.) Institute of Marine Sciences and Technology. The processing and interpretation of the collected data is supported by Çanakkale Onsekiz Mart University Scientific Research Projects Coordination Unit FBA-2018-2724. 


\section{REFERENCES}

AKSU, A.E., PIPER, D.J.W. ve KONUK, T., (1987). Late Quaternary tectonic and Sedimentary history of outer İzmir ans Çandarlı bays, western Turkey. Marine Geophysics, (76), 89-104.

AKSU, A.E., KONUK, T., ULUĞ, A., DUMAN, M., PİPER, D.J.W., (1990). Quaternary tectonic and sedimentary history of Eastern Aegean Sea shelf area. Geophysics, (4), 335.

BENETATOS, C., KIRATZI, A., GANAS, A., ZIAZIA, M., PLESSA, A. \& DRAKATOS, G. (2006). Strike Slip Motions in the Gulf of Siğacık (western Turkey): Properties of the 17 October 2005 earthquake seismic sequence. Tectonophysics, 426, 263-279

ÇİFÇİ, G., DONDURUR, D., OKAY, S. (2005), Yüksek ayrımlı deniz jeofiziği yöntemleri, Jeofizik Mühendisleri Odas1

OCAKOĞLU, N., DEMİRBAĞ, E. \& KUŞÇU, I. (2004). Neotectonic structures in the area offshore of Alaçati, Doğanbey and Kuşadasi (western Turkey): evidence of strike-slip faulting in the Aegean extensional province. Tectonophysics, 391, 67- 83.

OCAKOĞLU, N., DEMIRBAĞ, E. \& KUŞÇU, I. (2005). Neotectonic structures in Izmir Gulf and surrounding regions (western Turkey): Evidences of strike-slip faulting with compression in the Aegean extensional regime. Marine Geology, 219, 155-171.

QUINN, R., BULL, J.M. and DIX, J.K. (1998). Optimal Processing of Marine High-Resolution Seismic Reflection (CHIRP) Data, Marine Geophysical Researches, 20, 13-20.

TAN, O. \& TAYMAZ, T. (2001). Source parameters of November 6, 1992 Doganbey (İzmir) earthquake $(\mathrm{Mw}=6.0)$ obtained from inversion of teleseismic body-waveforms. 4th International Turkish Geology Symposium, 171.

TAN, O. \& TAYMAZ, T. (2003). Seismotectonics of Karaburun Peninsula and Kusadas1 Gulf: source parameters of April 2, 1996 Kusadası Gulf and April 10, 2003 Seferihisar (İzmir) earthquakes. International Workshop on the North Anatolian, East Anatolian and Dead Sea Fault Systems: Recent Progress in Tectonics and Paleoseismology and Field Training Course in Paleoseismology, Middle East Technical University, 147, Ankara. 